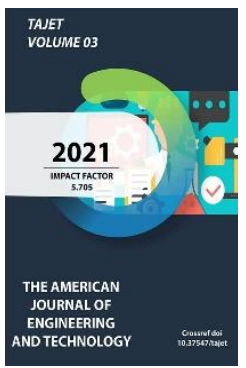

Copyright: Original content from this work may be used under the terms of the creative commons attributes 4.0 licence.

\section{Methodology Of Organization Of The Labor Process And Preservation Of Employees' Health}

\author{
Shovkiddin Narziev \\ PhD, Tashkent State Technical University, Tashkent, Uzbekistan \\ Javohir Asqarov \\ Master Student, Tashkent State Technical University, Tashkent, Uzbekistan \\ Azizbek Khokimyatov \\ Master Student, Andijan Machine-Building Institute, Andijan, Uzbekistan
}

\title{
ABSTRACT
}

In this article, the importance of carrying out production based on the legal framework of the organization, the relative physical loads of employees employed in the production, along with the lights of the employee's negative impact on labor productivity, as well as methods of preservation of health are presented. Recommendations were made to make the work process taking into account the energy consumption of the employees employed in the production.

\section{KEYWORDS}

Labor protection, work productivity, ergometer, useful work, production, labor activity, energy consumption, muscle work

\section{INTRODUCTION}

The measures taken to create working conditions in our country, improve the legal framework of Labor are an important factor in the protection of the rights and interests of citizens[1]. The law "on protection of labor"in the new edition was an important step in this 
direction. It is worth noting that it is defined as the main directions of public policy, such as ensuring the priority of the life and health of the employee, development and implementation of state programs in the field of labor protection, coordination of activities of state and economic management bodies and local government bodies in this field[1, 2$]$.

It should be noted that the modern state of the market economy and the results of work on deepening democratic reforms, liberalization of the economy, strengthening cooperation between state bodies and the private sector, development of entrepreneurial activity and labor legislation in the country are obvious examples of this[2, 3].

Therefore, an important task is entrusted to the employer, such as providing employees with guidance on technical safety, sanitation of production, avoidance of intensive exits and other rules of labor protection, as well as constantly checking the compliance of employees with all requirements of labor protection[4].

In addition, a number of ministries and industry agencies, large industrial enterprises, civil society institutions, trade unions representatives, industry experts create working conditions through the introduction into practice of innovative techniques by studying the conventions and recommendations of the International Labor Organization, the legislation of foreign countries on the protection of Labor and normative documents, as well as ensuring labor safety is of paramount

\section{MATERIALS}

Labor is an activity that is done to bring consumer values into existence. From the physiological side, this is the function of a person's organism, and each of such function, regardless of its content and form, is actually the expenditure of a person's brain, ASAPS, muscles, sensory organs, etc. $[5,6]$. In the process of Labor, the organism studies the change in life functions by the physiology of Labor.

In the process of labor, all the functions of the body, that is, muscle activity, oxidationreduction processes, etc., change dramatically. Before the start of the work, the functions of the person as soon as the fakat comes to work will be changed accordingly[6]. Usually the pulse accelerates and the amount spent in one minutda increases. In this conditional reflex change of functions, the "run mexanizms" of higher nerve activity come into motion. The activation effects of the pustlog of large hemispheres bring the body from a calm state, to an active state, or at this time sharply kuchaytiradi the activity that passes under internal influences. But the large hemispheres also continue to affect the organs on which the pustlog was launched. When the impulses from the brain pustloge affect the organs in which they work, pustlok shows the harmonization effect $[6,7]$.

The ability of a person to maintain the required level of work capacity or work capacity as long as possible without changing the quality of work depends on several factors. The most important of these is the emotional state of training and exercise, fatigue and surrounding conditions $[1,8]$. 
In order to measure the mechanical work and ability to perform laboratory tests in labor physics, special instruments are used ergometers, with the help of which it is possible to accurately calculate the magnitude of the load being lifted and the height of the lift or the length of the pathway with constant resistance, and thus measure useful work in kilograms-meters. Measuring work in production conditions is often difficult. But in this it is possible to clearly define "useful work". To do this, it is enough to measure the loads that are transported from one place to another, to measure the tracks and to measure the resistance with the help of dynamometers, for example, portable and genetics, rotatable richag, etc. $[1,5,8]$.

\section{RESEARCH METHODS}

The work performed in modern production conditions can be divided into 3 groups depending on their capacity, that is, the amount of work performed per unit of time: 1Light; 2 - medium; and 3-heavy work. The light work series includes jobs that consume less oxygen per minute. If we take into account the oxygen consumption of $200-250 \mathrm{~cm} 3$ per minute in a completely calm state,then the oxygen consumption in light working hours increases by 2-2.5 times. The range of mediumweight work includes work that consumes up to 1 liter per minute, that is, the oxygen consumption in this case increases 2-4 times more than in a calm state. Heavy work involves consuming more than one liter of oxygen per minute. The reason that oxygen is consumed in the cubes during work is because the energy needed for the muscles to work is generated as a result of the nutrients. But in some cases, the use of oxygen can be applied regardless of the amount of work performed. For example, when a person runs at a maximum speed for 13 seconds, the oxygen consumption is not overestimated, and then increases after the end of the run[9].

In order to eliminate or significantly reduce such negative work results that were improperly organized and require a lot of attention, it is necessary to improve sanitary and hygienic working conditions, organize work, take short breaks, and transfer workers from one operation to the second operation after a certain period of time[ 9 ,

Proper organization of safe working conditions at enterprises leads to the fact that employees are disciplined, and this, in turn, leads to an increase in labor productivity, a decrease in the frequency of accidents at work, equipment malfunctions and other unforeseen circumstances, and ultimately to an increase in production efficiency and stability of the enterprise[6].

Based on the above, statistical methods for determining the damage that occurred during its production are defined: grouping, coefficients, monographic, topographic and economic methods using weeks, days, hours under the influence of the factor of industrial injuries[11]. In accounting formulas, it is based on the fact that the factor of damage to the production of the employee(the participant) is in the zone of influence (in the"risk zone"). The probability of injury to an employee will be available only in the course of his work, in the zone of exposure to the traumatic factor inherent in this type of activity (in the"risk zone"). Because the factor of industrial injuries can be damaged in the zone of impact, that is, 
in a week, day, hour, which is "in the danger zone" [11]. Therefore, in the process of work, it is desirable to determine the frequency, weight, risk of injury in the impact zone, that is, in the "danger zone", the injury factor inherent in the type of work, according to the following formulas:

Frequency of injury $-K_{c h}$

$$
K_{c h}=\frac{n_{1}}{n_{o^{\prime}}} \cdot 1000
$$

here: $n_{1}$ - the number of workers who lost and lost their jobs due to an unfortunate accident;

$$
\mathrm{n}_{\mathrm{o}} \text { - average number of workers. }
$$

Weight of injury $-\mathrm{K}_{\mathrm{o}}$

$$
K_{0}=\frac{D_{i k}}{n_{2}}
$$

here: $D_{i k}$ - total number of working days lost during the reporting period;

$$
\mathrm{n}_{2} \text { - the number of workers who lost }
$$
their jobs.

Indicator of loss of working day $-\mathrm{K}_{\mathrm{ik}}$

$$
K_{i k}=\frac{D_{i k}}{n_{o^{\prime}}} \cdot 1000, \%
$$

The analysis shows that one of the reasons for the occurrence of Unfortunate Events associated with the production taking place in enterprises is that employees do not comply with the requirements for the protection of Labor and the rules of safety equipment. Sometimes, when determining the working time and rest time of employees by the employer, sending them on service trips, safety requirements are also encountered cases of violations(see figure-1).

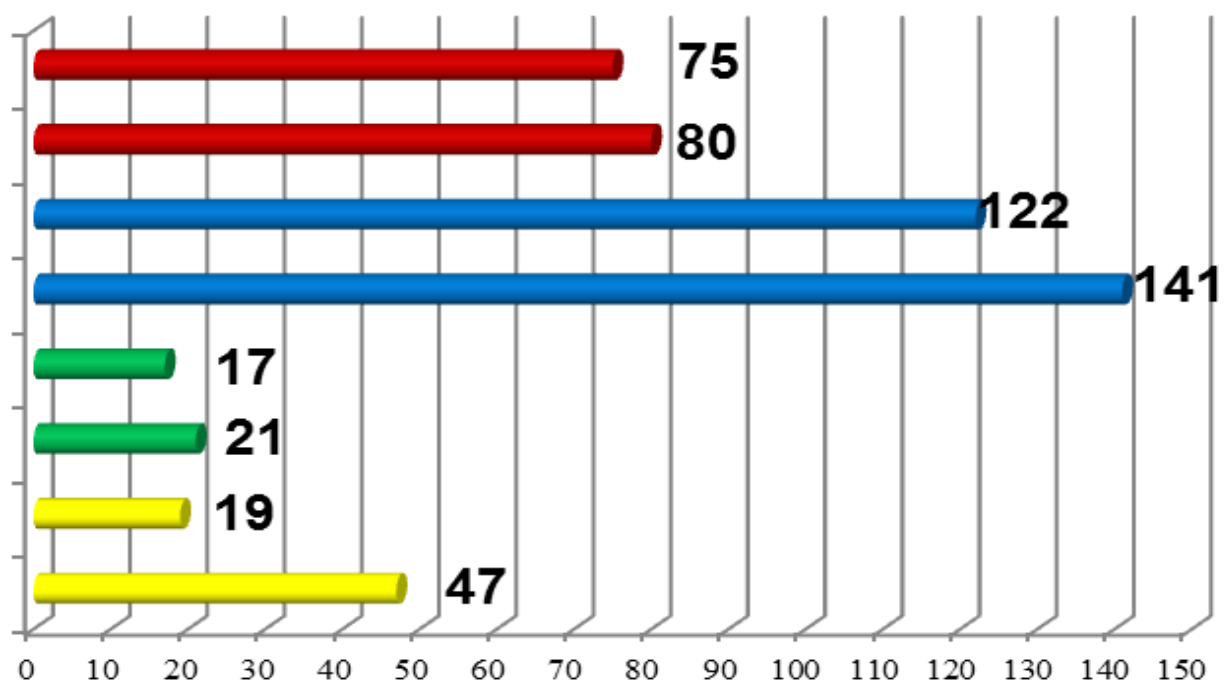


75-finished with death; 80-the dead; 122-the end is heavy ; 141-seriously injured; 17-the end is light; 21lightly injured; 19-group; 47 - injured.

\section{1-Figure. Undesirable working conditions in production can occur as a consequence of unhappy employees.}

\section{CONCLUSIONS}

1. It provides a direct application of the method of coefficients based on the statistics of unhappy employees introduced in the practice of labor protection in production to the study of the situation.

2. It is necessary to organize working conditions in the production on the basis of labor protection standards

3. It is necessary to introduce into practice a single electronic system of documents on the study and accounting of employee's health disorders, injuries and occupational diseases.

4. Attention should be paid to factors affecting the health of employees in labor activity,

5. It is necessary to conduct labor protection measures in the conduct of public control over the observance of normative documents on labor.

\section{REFERENCES}

1. E.I.Ibragimov, S.Gazinazarova, O.R.Yuldashev. Special course of labor protection. Textbook.-T.: TIMI, 2014.-536 p.
2. Narziev S. et al. Theoretical analysis of the causes of injury in sports activities and their reduction measures //Journal of Advanced Research in Dynamical and Control Systems. - 2020. - T. 12. - №. S2. C. 166-170.

3. Sulaimanovich, S. S., \& Murtozaevich, H. S. Causes and Prevention of Athlete Injuries During Training Sessions and Competitions. JournalNX, 325-329.

4. Shovkiddin, N., Eleonora, Y., Surayo, A., Nargiza, K., \& Saodat, N. (2020). PROBLEMS OF ENSURING THE SAFETY OF SPORTS ACTIVITIES AND REDUCING INJURIES. Journal of Critical Reviews, 7(11), 428-432.

5. Sulaymonovich, S. S., \& Murtozayevich, N. S. (2020). Studying and accounting sports injuries. ACADEMICIA: An International Multidisciplinary Research Journal, 10(7), 759-763.

6. Нарзиев Шовкиддин Муртозаевич, Ботиров Акбар Бахриддинович БЕЗОПАСНОСТЬ ДЕЯТЕЛЬНОСТИ ЧЕЛОВЕКА МЕТОДЫ ИЗУЧЕНИЯ И АНАЛИЗА РИСКОВ В ТРУДОВОМ ПРОЦЕССЕ // ТЕСНика. 2021. №1 (5). URL: https://cyberleninka.ru/article/n/bezopasn ost-deyatelnosti-cheloveka-metodyizucheniya-i-analiza-riskov-v-trudovomprotsesse (дата обращения: 08.04.2021). 
7. Sulaymonovich S. S. et al. Methods of Forecasting and Occurrence of Traumatic Damages i Sport //International Journal of Innovative Technology and Exploring Engineering. - 2019. - T. 8. - №. 9 S2. - pp. 223-225.

8. Sulaimanovich S. S., Murtozaevich H. S. Causes and Prevention of Athlete Injuries During Training Sessions and Competitions //JournalNX. - pp. 325-329.

9. Occupational health. Iskandarova G.T. ostida editor. - T., 2009, - 283 b.

10. Нарзиев, Ш. М., \& Рахимова, А. Х. К. (2021). ПРИМЕНЕНИЕ И АНАЛИЗ ПЕДАГОГИЧЕСКИХ МЕТОДОВ В УЧЕБНОМ ПРОЦЕССЕ. ТЕСНИка, (1 (5)).

11. Shovkiddin, N., Elleonora, Y., Nargiza, X., Surayyo, A., \& Pulat, S. (2021). PROVISION OF LABOR PROTECTION AND ANALYSIS OF INJURIES OF ACTIVE PARTICIPANTS. Journal of Contemporary Issues in Business and Government, 27(2), 1902-1909. 